\title{
Serum theophylline levels in asthmatic children after oral administration of two slow-release theophylline preparations
}

\author{
SHEILA MCKENZIE AND EIVOR BAILLIE \\ From the Department of Paediatrics and Neonatal Medicine, Hammersmith Hospital, London
}

SUMMARY Serum theophylline levels were measured throughout the day in 65 asthmatic children receiving one of two slow-release theophylline compounds. There was a wide interindividual variation in levels obtained with similar doses of pure theophylline, and also a wide intraindividual variation in levels throughout the day, suggesting that the rates of release and/or absorption of theophylline from these compounds are not uniform. There were fewer side effects associated with taking these compounds than with choline theophyllinate.

Oral theophylline has been shown to be efficacious in the treatment of patients with chronic perennial asthma provided serum levels lie between 10 and $20 \mu \mathrm{g} / \mathrm{ml}$ (Jenne et al., 1972; Weinberger and Bronsky, 1974). Ellis et al. (1976) have shown that the biological half-life of theophylline in children is short, ranging from 1.4 to 7.8 hours. To maintain therapeutic levels oral theophylline must therefore be given at least every 6 hours to most children. As the average child sleeps for longer than 6 hours this short interval is impracticable. A 3- or 4-times a day regimen, while providing adequate levels during the day (McKenzie et al., 1978a), will give subtherapeutic levels before the morning dose in most children. A slow-release theophylline preparation which needs to be administered only twice daily would seem to be a welcome addition to the range of oral theophylline preparations.

The purpose of the present study was to measure serum theophylline levels after administration of one of two slow-release theophylline preparations given 12-hourly.

\section{Patients and methods}

Preparations. The drugs used in the study were aminophylline incorporated in a lipid base and marketed as 100 and $225 \mathrm{mg}$ tablets*, and pure theophylline incorporated in sucrose starch pellets and marketed as 60,125 , and $250 \mathrm{mg}$ capsules†.

Received 23 February 1978

*Phyllocontin, Napp Laboratories Ltd.

†Slophyllin, Rona Laboratories Ltd.
Both preparations are designed to give sustained release of the active theophylline component.

Patients. 65 children with chronic perennial asthma who were considered to need continuous treatment were studied on 71 occasions. 27 children (mean age 8 years, range 3-14) received slow-release aminophylline (S-RA). 12 received a low dose regimen (mean $9.6 \mathrm{mg} / \mathrm{kg}$ per dose, range 6.9-11.8), 12 received a high dose regimen (mean $13.5 \mathrm{mg} / \mathrm{kg}$ per dose, range $11 \cdot 9-15 \cdot 5)$, and 3 children received both low and high dosages. 38 children (mean age 7 years, range 15 months-14 years) received slowrelease pure theophylline (S-RT). 13 received a low dose regimen (mean $7 \mathrm{mg} / \mathrm{kg}$ per dose, range 3.3-9.9), 22 received a high dose regimen (mean $12 \mathrm{mg} / \mathrm{kg}$ per dose, range $10-15$ ), and 3 received both low and high dosages.

Children who could not swallow S-RA tablets were either not included in the study or were given S-RT capsules. Those who could not swallow S-RT capsules had them broken into a small amount of jam or orange juice. The importance of not chewing the tablets or capsules was stressed. The medication was given at $0800 \mathrm{~h}$ and $2000 \mathrm{~h}$ and all children took it for at least 48 hours before serum theophylline measurements were made. On the day of the study blood was drawn either from an indwelling heparinised needle or by finger prick before the $0800 \mathrm{~h}$ dose and then every 2 hours until the next dose. 23 children were also studied at night. If the indwelling needle dislodged or the finger pricks became too distressing the series was abandoned. 
Serum or plasma theophylline was measured by high pressure liquid chromatography (McKenzie et al., 1978b).

\section{Results}

The serum theophylline levels throughout the day are shown in Table 1. The levels in the children studied at night were of the same order but were too few to compare statistically with daytime levels. Five children had at least 11 measurements made throughout the day and night and these are presented in the Figure.

The mean maximum and minimum levels on 45 children who had 5 measurements or more are shown in Table 2. Two children had two series of measurements, one on a high and one on a low dose. The difference between maximum and minimum levels was $<4 \mu \mathrm{g} / \mathrm{ml}$ in 6 children receiving S-RA and in 8 children receiving S-RT. Peak levels in the remaining 33 series of 5 or more measurements occurred between 2 and 6 hours (Table 3).

To determine whether age made any difference to levels obtained with similar doses of S-RT preparations the mean of the 2-, 4-, and 6-hour levels was calculated for each child who had these 3 levels measured. For dosages of between 8 and $12 \mathrm{mg} / \mathrm{kg}$ per dose in children taking S-RT a Student's $t$ test showed there was no significant difference between levels obtained in children $<5$ years, 5-10 years, and $>10$ years old. Similarly, for dosages of between 10 and $15 \mathrm{mg} / \mathrm{kg}$ per dose of S-RA there was no

Table 1 Serum theophylline levels during the day $(\mu \mathrm{g} / \mathrm{ml})$ with two slow-release theophylline preparations

\begin{tabular}{|c|c|c|c|c|c|c|c|c|}
\hline \multirow[t]{2}{*}{ Drug } & \multirow{2}{*}{$\begin{array}{l}\text { Daily } \\
\text { dosage } \\
(m g / k g)\end{array}$} & \multicolumn{7}{|l|}{ Before } \\
\hline & & $0800 h$ & $1000 \mathrm{~h}$ & $1200 h$ & $1400 h$ & $1600 h$ & $1800 \mathrm{~h}$ & $2000 h$ \\
\hline \multicolumn{9}{|l|}{ S-RA (low dose) } \\
\hline $\begin{array}{l}\text { Mean } \\
\text { Range } \\
\mathbf{n}\end{array}$ & $\begin{array}{l}9 \cdot 6 \\
6 \cdot 9-11 \cdot 8 \\
15\end{array}$ & $\begin{array}{l}6 \cdot 0 \\
3-10 \\
11\end{array}$ & $\begin{array}{l}9.4 \\
3-17 \\
14\end{array}$ & $\begin{array}{l}11 \cdot 7 \\
5-22 \\
12\end{array}$ & $\begin{array}{l}11 \cdot 7 \\
6-23 \\
10\end{array}$ & $\begin{array}{l}9.7 \\
4-22 \\
11\end{array}$ & $\begin{array}{l}8 \cdot 7 \\
4-21 \\
10\end{array}$ & $\begin{array}{l}8 \cdot 0 \\
1-19 \\
7\end{array}$ \\
\hline \multicolumn{9}{|l|}{ S-RA (high dose) } \\
\hline $\begin{array}{l}\text { Mean } \\
\text { Range } \\
\text { n }\end{array}$ & $\begin{array}{l}13 \cdot 5 \\
11 \cdot 9-15 \cdot 5 \\
15\end{array}$ & $\begin{array}{l}10 \cdot 5 \\
4-17 \\
10\end{array}$ & $\begin{array}{l}16 \cdot 5 \\
10-25 \\
11\end{array}$ & $\begin{array}{l}17 \cdot 7 \\
7-27 \\
14\end{array}$ & $\begin{array}{l}15 \cdot 7 \\
10-23 \\
10\end{array}$ & $\begin{array}{l}13 \cdot 8 \\
8-21 \\
10\end{array}$ & $\begin{array}{l}12 \\
6-17 \\
8\end{array}$ & $\begin{array}{l}6 \cdot 0 \\
4-10 \\
4\end{array}$ \\
\hline \multicolumn{9}{|l|}{ S-RT (low dose) } \\
\hline Mean & $7 \cdot 0$ & $5 \cdot 6$ & $5 \cdot 8$ & $7 \cdot 5$ & $6 \cdot 6$ & $5 \cdot 7$ & $5 \cdot 0$ & 3.6 \\
\hline Range & $3 \cdot 3-9 \cdot 9$ & $<1-14$ & $2-13$ & 3-14 & $3-10$ & $2-9$ & $2-9$ & $2-9$ \\
\hline n & 16 & & 11 & 15 & 11 & 10 & 9 & 9 \\
\hline S-RT (high dose) & $12 \cdot 0$ & $6 \cdot 5$ & 11.9 & $12 \cdot 8$ & $12 \cdot 7$ & $12 \cdot 0$ & $9 \cdot 7$ & $8 \cdot 0$ \\
\hline Range & $10 \cdot 0-15 \cdot 0$ & $<1-20$ & $5-22$ & $4-24$ & $5-22$ & $4-25$ & $6-22$ & $2-20$ \\
\hline $\mathrm{n}$ & 25 & & 19 & 19 & 21 & 15 & 16 & 12 \\
\hline
\end{tabular}

$\mathrm{n}=$ total number of measurements.

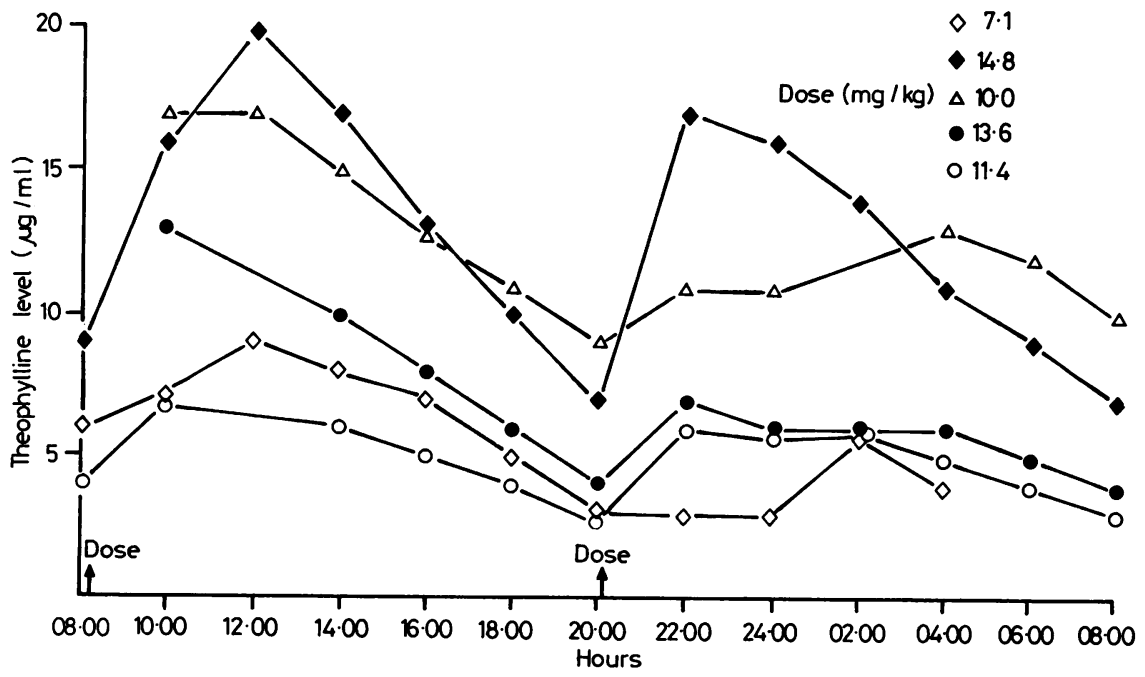

Figure 24-hour serum theophylline profiles in 5 children taking $S-R A$. 
Table 2 Maximum and minimum serum theophylline levels $(\mu \mathrm{g} / \mathrm{ml})$ during the day (0800-1800h) in children who had 5 or more measurements

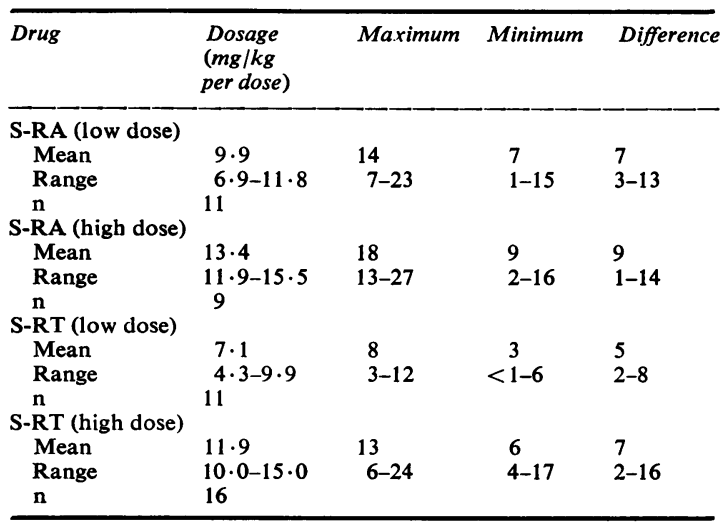

$\mathrm{n}=$ total number of measurements.

Table 3 Time of peak levels in those children with a difference of $>4 \mu \mathrm{g} / \mathrm{ml}$ between maximum and minimum serum theophylline levels

\begin{tabular}{lccc}
\hline Children taking & $2 h$ & $4 h$ & $6 h$ \\
\hline S-RA & 4 & 7 & 3 \\
S-RT & 3 & 12 & 4 \\
\hline
\end{tabular}

significant difference between levels obtained in children aged 5-10 and those $>10$ years. Only 2 children in the S-RA group were $<5$ years old and so no comparison could be made.

To determine whether similar doses of pure theophylline in the S-RA preparation $(85 \%$ pure theophylline) and the S-RT preparation gave similar serum theophylline levels, the mean of the 2-, 4-, and 6-hour levels in all children taking S-RA who had these 3 levels measured, was plotted against the dose of S-RA as pure theophylline. Similarly a plot was made for levels obtained with S-RT. A comparison of regression lines for these 2 plots showed there was no significant difference between them. Similarly when predose levels were plotted against the dose of pure theophylline there was no significant difference between S-RA and S-RT.

Of all 65 children studied only 7 were shown to have levels $>20 \mu \mathrm{g} / \mathrm{ml}$ (Table 4). One of these children was on the low dose regimen. All 7 were asymptomatic. During the period of the study, two other children had sleeping difficulties (nightmares and insomnia) but neither had levels $>20 \mu \mathrm{g} / \mathrm{ml}$. No child had nausea or vomiting.

\section{Discussion}

The first line of treatment of children with chronic perennial asthma is administration of either sodium cromoglycate or a theophylline compound, usually choline theophyllinate. These drugs control symptoms equally well (Hambleton et al., 1977). For maximum efficacy choline theophyllinate must be given 4 times a day (Ginchansky and Weinberger, 1977) and many children need at least 4 doses of sodium cromoglycate a day for satisfactory control (König and Godfrey, 1973). Slow-release theophylline compounds which need be administered only twice daily may therefore supersede both sodium cromoglycate and choline theophyllinate, provided serum theophylline levels are within the therapeutic range for most of the day. The only disadvantage is that these preparations must not be crushed or chewed. Very young children in this study were given S-RT capsules in preference to S-RA tablets because the pellets inside the capsules were easier to swallow.

The half-life of theophylline varies 7 -fold from individual to individual (Ellis et al., 1976). The results in this study demonstrate a wide variation between individuals in serum theophylline levels obtained with similar doses of both S-RA and S-RT, and also a wide variation in levels throughout the day in many children. Of the 45 children who had 5 or more levels measured during a 24-hour period, $69 \%$ had peak-trough differences of $>4 \mu \mathrm{g} / \mathrm{ml}$. One child had a peak-trough difference of as much as $16 \mu \mathrm{g} / \mathrm{ml}$.

The rate of release of the theophylline or aminophylline from the slow-release preparation, the rate

Table 4 Dosages of $S-R A$ and $S-R T$ giving serum theophylline levels $>20 \mu g / m l$ in 7 children

\begin{tabular}{|c|c|c|c|c|c|c|c|c|}
\hline \multirow[t]{2}{*}{ Drug } & \multirow{2}{*}{$\begin{array}{l}\text { Age of } \\
\text { patient } \\
\text { (years) }\end{array}$} & \multirow{2}{*}{$\begin{array}{l}\text { Dosage } \\
\mathrm{mg} / \mathrm{kg} \\
\text { per dose }\end{array}$} & \multicolumn{6}{|c|}{ Serum theophylline levels $(\mu \mathrm{g} / \mathrm{ml})$} \\
\hline & & & Before dose & $2 h$ & $4 h$ & $6 h$ & $8 h$ & $10 h$ \\
\hline S-RA & $\begin{array}{r}10 \\
14 \\
11 \\
8\end{array}$ & $\begin{array}{l}11 \cdot 6 \\
11 \cdot 9 \\
12 \cdot 3 \\
14 \cdot 3\end{array}$ & $\begin{array}{l}16 \\
12 \\
10\end{array}$ & $\begin{array}{l}15 \\
23 \\
21 \\
25\end{array}$ & $\begin{array}{l}22 \\
27 \\
22 \\
24\end{array}$ & $\begin{array}{l}23 \\
23 \\
\\
20\end{array}$ & $\begin{array}{l}22 \\
21 \\
17\end{array}$ & $\begin{array}{l}21 \\
17 \\
13\end{array}$ \\
\hline S-RT & $\begin{array}{r}9 \\
9 \\
10\end{array}$ & $\begin{array}{l}12 \cdot 5 \\
15 \cdot 0 \\
15 \cdot 0\end{array}$ & $\begin{array}{l}16 \\
20 \\
20\end{array}$ & $\begin{array}{l}20 \\
22\end{array}$ & 24 & $\begin{array}{l}22 \\
21 \\
22\end{array}$ & $\begin{array}{l}19 \\
19 \\
25\end{array}$ & $\begin{array}{l}17 \\
22\end{array}$ \\
\hline
\end{tabular}


and uniformity of absorption from the gastrointestinal tract, and the plasma clearance rate of the drug, all determine the serum theophylline levels obtained in each child. The peak levels obtained occurred within 2-6 hours after ingestion of the dose. This would suggest that if the absorption rate is uniform the release of the drug from the preparation is faster at this time or occurs entirely within this time. Alternatively if the rate of release of the drug is uniform, the absorption rate is slower after 6 hours. Many factors influence the rate of release of a drug from a slow-release preparation (Lazarus et al., 1964) and the variability in the rate of absorption of drugs from these preparations is well known (Goldstein et al., 1974). Therefore when a drug such as theophylline which has a known large interindividual variation in plasma clearance rate is incorporated into a slow-release preparation, it would be surprising if there were not a large intraindividual variation in serum levels obtained throughout the day.

Ginchansky and Weinberger (1977) showed that there is an inverse relationship between theophylline clearance rate and age. In our study however there appeared to be no difference in the dosage required to produce the same levels in children of different ages, probably because the levels obtained do not depend entirely on the theophylline clearance rate.

SR-A, when the dosage was corrected to dosage of pure theophylline, produced similar theophylline levels in the period 2-6 hours after ingestion as SR-T and had similar predose levels.

Sleep disturbance in 2 children was the only side effect reported during the study. Neither preparation was associated with nausea or vomiting, unlike choline theophyllinate (McKenzie et al., 1978b). Eney and Goldstein (1976) showed that compliance in taking choline theophyllinate at home is not good. It may be that the few side effects together with the longer time between doses for these slowrelease preparations will improve compliance. One of the disadvantages of treatment is the limited number of tablet and capsule sizes. The tailoring of doses to suit the child is therefore difficult as the tablets or capsules must not be divided. Parents should be made aware of the potential dangers of dividing or chewing slow-release preparations. In addition, aminophylline should be given with caution to a child with acute asthma if he has received a slow-release theophylline preparation in the previous 12 hours. A knowledge of the serum theophylline level would help to plan aminophylline treatment in such a child (McKenzie et al., 1978b).
Of a total of 40 children receiving as near as possible $14 \mathrm{mg} / \mathrm{kg}$ per dose twice daily of S-RA, or as near as possible $12 \mathrm{mg} / \mathrm{kg}$ per dose twice daily of S-RT, only 6 were shown to have levels $>20 \mu \mathrm{g} / \mathrm{ml}$ and none was symptomatic. We suggest these as suitable starting doses for treatment of asthma with slow-release theophylline preparations. Because they may give levels outside the therapeutic range in some children, levels should be measured at 2, 4, and 6 hours after ingestion of the dose-i.e. over the timeperiod when the peak is expected, and just before administration, the time when the trough level is expected.

\section{References}

Ellis, F. E., Koysooko, R., and Levy, G. (1976). Pharmacokinetics of theophylline in children with asthma. Pediatrics, 58, 542-547.

Eney, E. D., and Goldstein, W. O. (1976). Compliance of chronic asthmatics with oral administration of theophylline as measured by serum and salivary levels. Pediatrics, 57, 513-517.

Ginchansky, E., and Weinberger, M. (1977). Relationship of theophylline clearance to oral dosage in children with chronic asthma. Journal of Pediatrics, 91, 655-660.

Goldstein, A., Aronow, L., and Kalman, S. M. (1974). Principles of Drug Action. The Basis of Pharmacology, second edition. Wiley: New York.

Hambleton, G., Weinberger, M., Taylor, J., Cavanaugh, M., Ginchansky, E., Godfrey, S., Tooley, M., Bell, T., and Greenberg, S. (1977). Comparison of cromoglycate (cromolyn) and theophylline in controlling symptoms of chronic asthma. Lancet, 1, 381-385.

Jenne, J. W., Wyze, E., Rood, F. S., and MacDonald, F. M. (1972), Pharmacokinetics of theophylline: applicaiion to adjustment of the clinical dose of aminophylline. Clinical Pharmacology and Therapeutics, 13, 349-360.

König, P., and Godfrey, S. (1973). The effect of frequent administration of sodium cromoglycate to asthmatic children who previously responded poorly. Clinical Allergy, 3, 395-402.

Lazarus, J., Pagliery, M., and Lachman, L. (1964). Factors influencing the release of a drug from a prolonged-action matrix. Journal of Pharmaceutical Science, 53, 798-802.

McKenzie, S. A., Baillie, E., and Godfrey, S. (1978a). Effect of practical timing of dosage on theophylline blood levels in asthmatic children treated with choline theophyllinate. Archives of Disease in Childhood, 53, 167-168.

McKenzie, S. A., Edmunds, A. T., Baillie, E., and Meek, J. H. (1978b). Clinical applications of serum theophylline measurement by high pressure liquid chromatography. Archives of Disease in Childhood. 53, 322-325.

Weinberger, M., and Bronsky, E. A. (1974). Evaluation of oral bronchodilator therapy in asthmatic children. Journal of Pediatrics, 84, 421-427.

Correspondence to Dr S. McKenzie, Department of Paediatrics and Neonatal Medicine, Institute of Child Health, Hammersmith Hospital, Du Cane Road, London W12 0HS. 